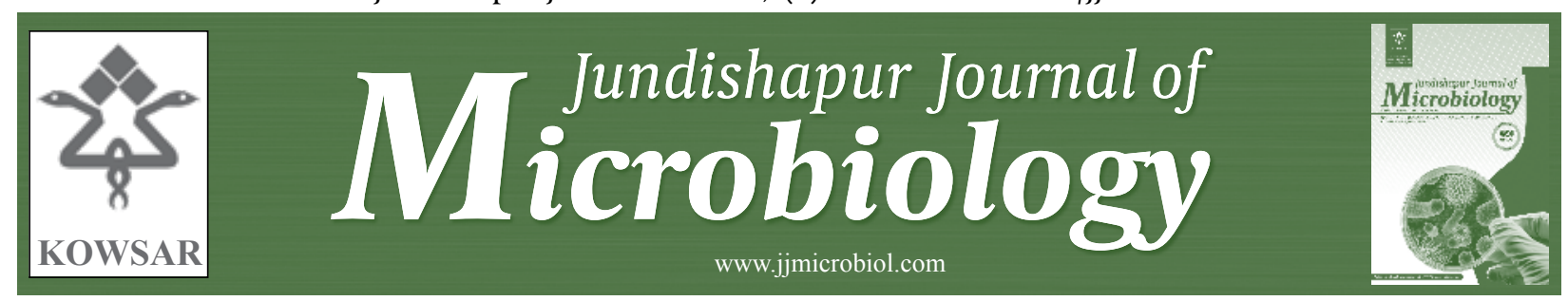

\title{
Antioxidant and Antibacterial Properties of Methanolic Extract of Green Seaweed Chaetomorpha linum From Gulf of Mannar: Southeast Coast of India
}

\author{
Palanisamy Senthilkumar ${ }^{1}$, Sellappa Sudha ${ }^{1^{*}}$ \\ ${ }^{1}$ Molecular Diagnosis and Drug Discovery Laboratory, Department of Biotechnology, School of Life Sciences, Karpagam University, Coimbatore, Tam- \\ ilnadu, India
}

\section{A R T I C L E I N F O \\ Article type: \\ Original Article \\ Article history: \\ Received: 15 May 2011 \\ Revised: 28 Oct 2011 \\ Accepted: 02 Nov 2011}

\section{Keywords:}

Chaetomorpha linum

Antioxidant

Antibacterial Agents

\begin{abstract}
A B S T R A C T
Background: Plants are an essential and integral part of complementary and alternative medicine due to their ability to generate secondary metabolites that are used to restore health and treat many diseases.

objectives: The aim of the present study was to determine the antioxidant and antibacterial activities of the green seaweed Chaetomorpha linum.

Materials and Methods: The antioxidant and antimicrobial activities of $C$. linum from the Mandapam coastal region of the Gulf of Mannar, on the southeast coast of India, were examined based on the free radical-scavenging activity of the 1, 1-diphenyl-2-picrylhydrazyl radical (DPPH), ferrous reducing antioxidant property (FRAP), and total phenolic content in the methanolic extract. The antibacterial properties of the methanolic extract of $C$. linum were tested against pathogenic bacterial strains, including Staphylococcus aureus, Bacillus cereus, Escherichia coli, Proteus mirabilis, Klebseilla pneumoniae, and Salmonella typhimurium, by cup-plate agar diffusion method.

Results: The DPPH scavenging activity was equivalent to an IC ${ }_{50}$ value of $9.8 \mu \mathrm{g} / \mathrm{mL}$ ascorbic acid. The total phenolic content was $672.3 \mathrm{mg} / \mathrm{g}$ gallic acid equivalent, and the $\mathrm{IC}_{50}$ value by FRAP assay was $8.2 \mu \mathrm{g} / \mathrm{mL}$. The C. linum extract showed significant activity against the majority of bacteria, comparable with standard antibiotics.

Conclusions: C. linum has potential as a natural antioxidant and a natural source of antimicrobials against many microbes.
\end{abstract}

Copyright $\odot 2012$ Kowsar Corp. All rights reserved.

- Implication for health policy/practice/research/medical education:

The $C$. linum may be used as an effective antioxidant and antimicrobial agents to combat various ailments caused by the free radicals and the microbial species.

Please cite this paper as:

Senthilkumar P, Sudha S. Antioxidant and Antibacterial Properties of Methanolic Extract of Green Seaweed Chaetomorpha linum From Gulf of Mannar: Southeast Coast of India. Jundishapur J Microbiol.2012;5(2):411-5. DOI:10.5812/jjm.3400

\section{Background}

In biomedicine, much attention has been paid to natural antioxidants and their association with health benefits (1). Many studies have on the biological activities of seaweed have reported it to be a potential source of

* Corresponding author: Sudha Sellappa, Department of Biotechnology, Karpagam University, Coimbatore-641 021. Tamilnadu, India. Tel: +914222611146; Fax:+91-4222611043, E-mail: sudhasellappa@gmail.com

DOI: $10.5812 /$ jjm.3400

Copyright $\odot 2012$ Kowsar Corp. All rights reserved. natural antioxidants $(2,3)$. Among the features of marine algae and its components, several extracts have been screened with regard to antioxidant and radical scavenging activity, using stable free radicals (4-7).

Traditionally, seaweeds have been used in the treatment of various infectious diseases. Many substances obtained from seaweeds have been used for decades in medicine and pharmacotherapy, whereas some of the isolated substances have bacteriostatic and bactericidal properties (8-11). Furthermore, several groups have investigated the properties of green, red, and brown seaweed $(12,13)$. 
Chaetomorpha linum, a green seaweed that is widespread in the Mandapam coastal region of the Gulf of Mannar on southeast coast of India. (Class: Ulvophyaceae; Order: Cladoporales; Family: Cladoporaceae), is mainly used for food, animal feed, and agriculture.

The majority of seaweeds from the Gulf of Mannar have not been examined for their bioactive substances, and until now, no screen of antioxidant activities has been performed with C. linum,despite the abundance and diversity of algae in coastal waters (Southeast coast of India).

\section{Objectives}

In this investigation, we evaluated the antioxidant and antibacterial activity of a methanolic extract of $C$. linum, obtained from the Gulf of Mannar, a southeastern coastal region of India.

\section{Materials and Methods}

\subsection{Chemicals}

DPPH (2,2 diphenyl - 1 picryldrazylhydrate) and ascorbic acid were purchased from Hi media (Mumbai, India), and potassium ferricyanide was obtained from Merck (Mumbai, India). All other chemicals were obtained commercially and were analytical-grade.

\subsection{Sample collection}

In the present study, C. linum (Muller) Kutzing green seaweed was collected from the Mandapam coastal region $\left(78^{\circ} 8^{\prime} \mathrm{E}, 9^{\circ} 17^{\prime} \mathrm{N}\right)$, in the Gulf of Mannar, Tamilnadu, South India, on low tide in December 2009, brought immediately to the laboratory in polythene bags, and washed several times with seawater to remove sand, mud, and attached fauna. The algae was cleaned using a brush to remove epiphytes with distilled water. After cleaning, the algae was dried in the shade at room temperature for 1 week. The dried algal materials were homogenized to a fine powder and subjected to extraction.

\subsection{Preparation of Extracts}

Five hundred grams of powdered C. linum seaweed sample was taken and extracted successively with methanol (90\%) using a soxhlet apparatus. The crude extracts were later concentrated under reduced pressure to obtain their corresponding residues. The methanolic extracts were further subjected to antioxidant and antibacterial assays in triplicate.

\subsection{DPPH Radical Scavenging Assay}

The radical-scavenging activity of methanolic C. linum extracts against DPPH radicals was determined by the method of Blois et al (14). DPPH (0.1 mM in methanol) was prepared, and $1.0 \mathrm{~mL}$ of this solution was added to $3.0 \mathrm{~mL}$ of extract in methanol at various concentrations $(1-16 \mu \mathrm{g}$ ) $\mathrm{mL}$ ). Thirty minutes later, the absorbance was measured at $517 \mathrm{~nm}$. A blank was prepared without extract. Ascorbic acid at various concentrations ( 1 to $16 \mu \mathrm{g} / \mathrm{mL}$ ) was used as the standard. A lower absorbance of the reaction mixture indicates greater free radical-scavenging activity. The ability to scavenge DPPH radical was calculated using the following equation:

DPPH Scavenged (\%) $=\mathrm{A}_{\text {control }}-\mathrm{A}_{\text {test }} / \mathrm{A}_{\text {control }} \mathrm{X} 100$

where $A_{\text {control }}$ is the absorbance of the control reaction and $\mathrm{A}_{\text {test }}$ is the absorbance in the presence of the extracts. The antioxidant activity of the $C$. linum extract was expressed as $\mathrm{IC}_{50}$ and compared with the standard. The $\mathrm{IC}_{50}$ value was defined as the concentration (in $\mu \mathrm{g} / \mathrm{mL}$ ) of extract that inhibited the formation of DPPH radicals by reducing power assay.

The reducing power of methanolic extracts of $C$. linum was determined (15). Various concentrations of the extracts $(1-16 \mu \mathrm{g} / \mathrm{mL})$ in $1.0 \mathrm{~mL}$ of deionized water were mixed with phosphate buffer $(2.5 \mathrm{~mL})$ and potassium ferricyanide $(2.5 \mathrm{~mL})$. The mixture was incubated at $50^{\circ} \mathrm{C}$ for $20 \mathrm{~min}$, and aliquots of trichloroacetic acid $(2.5 \mathrm{~mL})$ were added to the mixture, which was then centrifuged at $3000 \mathrm{rpm}$ for $10 \mathrm{~min}$. The upper layer of the solution (2.5 $\mathrm{mL}$ ) was mixed with distilled water $(2.5 \mathrm{~mL})$ and freshly prepared ferric chloride solution $(0.5 \mathrm{~mL})$. The absorbance was measured at $700 \mathrm{~nm}$. A blank was prepared without extract. Ascorbic acid at various concentrations ( $1 \mathrm{to16} \mu \mathrm{g} / \mathrm{mL}$ ) was used as the standard. Increased absorbance of the mixture indicates an increase in reducing power.

\% Increase in Reducing Power $=A_{\text {test }} / A_{\text {blank }}-1 \times 100$

where $A_{\text {test }}$ is the absorbance of the test solution and $A$ blank is the absorbance of the blank. The antioxidant activity of the seaweed extract was expressed as $\mathrm{IC}_{50}$ and compared with the standard.

\subsection{Determination of Total Phenolic Content}

Total phenolic content of the C. linum extracts was determined using the Folin-ciocalteu reagent (16). One milliliter of extract in Gallic acid $(20,40,60,80$, and $100 \mathrm{mg} / \mathrm{L})$ was added to a $25-\mathrm{mL}$ volumetric flask, containing distilled deionized water. The blank reagent was distilled deionized water. One milliliter of Folin-ciocalteu phenol reagent was added to the mixture and mixed by shaking. After $5 \mathrm{~min}, 10$ $\mathrm{mL}$ of $7 \% \mathrm{Na}_{2} \mathrm{CO}_{3}$ solution was added to the mixture. The solution was diluted to $25 \mathrm{~mL}$ with deionized distilled water and mixed. After incubation for $90 \mathrm{~min}$ at room temperature, the absorbance against the prepared blank reagent was measured at $750 \mathrm{~nm}$ on a spectrophotometer. Total phenolic content of the seaweed was expressed as mg Gallic acid equivalents (GAEs) or $100 \mathrm{~g}$ fresh weight. All samples were analyzed in triplicate.

\subsection{Antibacterial Activity}

The following strains of bacteria were used:Staphylococcus aureus (MTCC No. 96), Bacillus cereus (MTCC No. 430), Escherichia coli (MTCC No. 443) Proteus mirabilis (MTCC No. 425), Klebseilla pneumoniae (MTCC No. 432), and Sal- 
monella typhimurium (MTCC No. 98) were obtained from the Institute of Microbial Technology, Chandigarh, India. Cultures were maintained on nutrient agar (Hi Media, India) slants at $4^{\circ} \mathrm{C}$ and were subcultured before use.

The antibacterial activity of $C$. linum was studied by cup-plate agar diffusion method (17). The turbidity of each bacterial suspension was adjusted the optical density a 0.5 McFarland standard, resulting in a suspension containing $1.5 \times 10^{8} \mathrm{CFU} / \mathrm{mL}$. Mueller- Hinton agar was prepared, inoculated with bacterial cultures, and transferred to sterile $15-\mathrm{cm}$ diameter Petri dishes. The medium in the plate was allowed to set at room temperature for 10 minutes and solidify for 30 minutes. Three wells (6-mm inner diameter) were made in each plate. Stock solutions of the test residual extract were prepared at concentrations of 100, 300, and $500 \mathrm{mg} / \mathrm{mL}$. One hundred microliters of each concentration was placed in the well with sterile pipettes. In each plate, 1 well was used for the control, standard, and test respectively. Chloramphenicol $(100 \mu \mathrm{g} / \mathrm{mL})$ was used as the standard, and the respective solvent was used as the control. The petri dishes were incubated for $16 \mathrm{~h}$ at $37^{\circ} \mathrm{C}$ and examined with regard to size of the zones of inhibition. Methanol was used as the control. The length of the inhibition zone was measured in millimeters from the edge of the well to the edge of the inhibition zone, and the results were tabulated.

\section{Results}

The DPPH antioxidant assay is based on the ability of $\mathrm{DPPH}$, a stable free radical, to decolorize in the presence of antioxidants. The comparison of the antioxidant activity of the extracts (at 1, 2, 4, 8, and $16 \mu \mathrm{g} / \mathrm{mL}$ ) and reference standard is shown in Table 1. The methanolic extract of $C$. linum exhibited a significant dose-dependent inhibition of DPPH activity, with an IC ${ }_{50}$ value of $9.8 \mu \mathrm{g} / \mathrm{mL}$. The $\mathrm{IC}_{50}$ value of the extract was comparable with that of the reference standard, ascorbic acid ( IC $_{50}=5.8 \mu \mathrm{g} / \mathrm{mL}$ ), indicating the antioxidant activity of $C$. linum. The $\mathrm{IC}_{50}$ value in the reducing power assay was $8.2 \mu \mathrm{g} / \mathrm{mL}$ and $3.2 \mu \mathrm{g} / \mathrm{mL}$, respectively, for the methanolic extract of $C$. linum and ascorbic acid. By Folin-Ciocalteu method, the highest total phenolic content of $C$. linum was $672.3 \mathrm{mg} / \mathrm{GAE} / 100 \mathrm{~g} /$ extract.

The methanolic extract of $C$. linum was tested for its antibacterial activity by cup-plate agar diffusion method. The results of the antibacterial studies with regard to zone of inhibition are shown in Table 2. The methanolic extract of $C$. linum exhibited activity against most of the tested strains, showing the highest activity against $B$. cereus and P. mirabilis $(500 \mu \mathrm{g} / \mathrm{mL})$ and the lowest activity against $E$. coli $(300 \mu \mathrm{g} / \mathrm{mL})$; no activity was observed against K. pneumoniae.

\section{Discussion}

The identification of antioxidants from medicinal plants is a fast-growing field of research, and many antioxidants have been investigated by several methods. The DPPH assay is a quick, reliable, and low-cost method that has frequently been used to evaluate the antioxidative potential of various natural compounds (18).

Methanolic extracts of $C$. linum exhibited potent antioxidant activity in a dose-dependent manner, by DPPH radical

\begin{tabular}{|c|c|c|c|c|}
\hline \multirow[t]{2}{*}{ Concentration, $\mu \mathrm{g} / \mathrm{mL}^{\mathrm{a}}$} & \multicolumn{2}{|c|}{ DPPH $^{\mathbf{b}}$ Radical Scavenging Activity, \% } & \multicolumn{2}{|c|}{ Reducing Power Activity, \% } \\
\hline & Chaetomorpha linum & Standard & Chaetomorpha linum & Standard \\
\hline 1 & $6.4 \pm 0.002$ & $16.98 \pm 0.002$ & $16.62 \pm 0.005$ & $24.04 \pm 0.002$ \\
\hline 2 & $14.57 \pm 0.001$ & $28.42 \pm 0.002$ & $25.82 \pm 0.006$ & $40.05 \pm 0.004$ \\
\hline 4 & $28.74 \pm 0.003$ & $42.55 \pm 0.007$ & $33.78 \pm 0.001$ & $58.58 \pm 0.003$ \\
\hline 8 & $45.32 \pm 0.001$ & $65.78 \pm 0.003$ & $49.17 \pm 0.006$ & $77.39 \pm 0.007$ \\
\hline 16 & $75.09 \pm 0.002$ & $92.91 \pm 0.002$ & $73.44 \pm 0.001$ & $83.41 \mathrm{l} \pm 0.001$ \\
\hline $\mathrm{IC}_{50}$ & $9.8 \mu \mathrm{g} / \mathrm{mL}$ & $5.8 \mu \mathrm{g} / \mathrm{mL}$ & $8.2 \mu \mathrm{g} / \mathrm{mL}$ & $3.2 \mu \mathrm{g} / \mathrm{mL}$ \\
\hline
\end{tabular}

\begin{tabular}{|c|c|c|c|c|c|c|}
\hline \multirow[t]{2}{*}{ Concentration, $\mu \mathrm{g} / \mathbf{m L}^{\mathbf{a}}$} & \multicolumn{2}{|c|}{ Gram Positive Organism } & \multicolumn{4}{|c|}{ Gram Negative Organism } \\
\hline & $\begin{array}{l}\text { Staphylococcus } \\
\text { aureus }\end{array}$ & Bacillus cereus & Escherichia coli & $\begin{array}{l}\text { Salmonella } \\
\text { typhimurium }\end{array}$ & $\begin{array}{l}\text { Proteus } \\
\text { mirabilis }\end{array}$ & $\begin{array}{l}\text { Klebsiella } \\
\text { Pneumoniae }\end{array}$ \\
\hline 100 & 11 & 21 & - & 15 & 22 & - \\
\hline 300 & 13 & 23 & 03 & 16 & 24 & - \\
\hline 500 & 14 & 27 & 05 & 17 & 25 & - \\
\hline Standard 100 & 23 & 23 & 24 & 25 & 23 & 22 \\
\hline Control & - & - & - & - & 1 & - \\
\hline
\end{tabular}

\footnotetext{
${ }^{\mathrm{a}}$ Each Value is Expressed As Average $(\mathrm{n}=3)$ : No Inhibition.
} 
quenching assay. The methanolic extract of $C$. linum contains a high amount of phenolic compounds, exhibited the greatest antioxidant activity (as ascorbic acid equivalents) in this study. The higher scavenging activity of $C$. linum may be attributed to hydroxyl groups in the phenolic compounds, which might provide the essential component.

Reducing power is associated with antioxidant activity In this study, the reduction of ferrous ion $\left(\mathrm{Fe}^{3+}\right)$ to ferric ion $\left(\mathrm{Fe}^{2+}\right)$ was measured in the methanolic extract of $C$. linum. All tested concentrations of methanolic extract showed significant activity when compared with the standard, ascorbic acid. The methanolic extract of $\mathrm{C}$. $l i$ num exhibited a concentration-dependent increase in reducing power. Phenolic compounds are major contributors to the antioxidant capacity of plants; function in plant defense mechanisms that counteract reactive oxygen species (ROS) to survive; and prevent molecular damage and damage by microorganisms, insects, and herbivores $(19,20)$. These antioxidants also possess diverse biological activities, such as anti-inflammatory and anticarcinogenic actions (21).

In this study, the maximum total phenolic content $C$. linum of was $672.3 \mathrm{mg} / \mathrm{GAE} / 100 \mathrm{~g} /$ extract. Many bioactive and pharmacologically active substances have been isolated from seaweeds and reported to exhibit antibacterial activity (22). The methanolic extract of $C$. linum showed strong antimicrobial activity against selected human pathogens and has considerable antimicrobial acitvity against a number of microorganisms. The largest zone of inhibition was observed against Bacillus cereus and Proteus mirabilis. These results are notable, because they were obtained with methanolic extracts, which are not pure products but have good potency. Our results should prompt further studies to isolate and identify the active compounds and evaluate a possible synergism between components with regard to their antioxidant and antimicrobial activity.

Considering the total phenolic content, reducing power, and DPPH radical scavenging activity as indices of antioxidant activity of the extract, our findings demonstrate its potential as a source of natural antioxidants, indicating that C. linum is a promising agent in scavenging free radicals and treating diseases that are related to free radical reactions. This work provides insight into the molecular basis of the therapeutic properties of $C$. linum in traditional medicine. The antibacterial study revealed that the methanolic extract of $C$. linum contains certain constituents with significant antibacterial properties. Detailed studies on the isolation and characterization of the plant extract as well as in vivo assays will be necessary to discover new biological antioxidants and antibiotics.

\section{Acknowledgments}

The authors are grateful to the authorities of Karpagam University, Coimbatore, Tamil Nadu, India for provid- ing facilities and for their encouragement. Authors also thank Dr. M. Ganesan, Scientist, CSMCRI- Marine Algal Research station, Mandapam camp, Tamilnadu, India for the species identification.

\section{Financial Disclosure}

None declared.

\section{Funding/Support}

None declared.

\section{References}

1. Kalim MD, Bhattacharyya D, Banerjee A, Chattopadhyay S. Oxidative DNA damage preventive activity and antioxidant potential of plants used in Unani system of medicine. BMC Complement Altern Med. 2010;10:77.

2. Airanthi MK, Hosokawa M, Miyashita K. Comparative antioxidant activity of edible Japanese brown seaweeds. J Food Sci. 2011;76 (1):C104-11.

3. Devi GK, Manivannan K, Thirumaran G, Rajathi FA, Anantharaman P. In vitro antioxidant activities of selected seaweeds from Southeast coast of India. Asian Pac J Trop Med. 2011;4 (3):205-11.

4. Cho SH, Kang SE, Cho JY, Kim AR, Park SM, Hong YK, et al. The antioxidant properties of brown seaweed (Sargassum siliquastrum) extracts. J Med Food. 2007;10 (3):479-85.

5. Devi KP, Suganthy N, Kesika P, Pandian SK. Bioprotective properties of seaweeds: in vitro evaluation of antioxidant activity and antimicrobial activity against food borne bacteria in relation to polyphenolic content. BMC Complement Altern Med. 2008;8:38.

6. Shanab SM, Shalaby EA, El-Fayoumy EA. Enteromorpha compressa exhibits potent antioxidant activity. J Biomed Biotechnol. 2011;2011:726405.

7. Yuan YV, Walsh NA. Antioxidant and antiproliferative activities of extracts from a variety of edible seaweeds. Food Chem Toxicol. 2006;44 (7):1144-50.

8. Gorban EN, Kuprash LP, Gorban NE. [Spirulina: perspectives of the application in medicine]. Lik Sprava. 2003 (7):100-10.

9. Nair R, Chabhadiya R, Chanda S. Marine algae: screening for a potent antibacterial agent. J Herb Pharmacother. 2007;7 (1):73-86.

10. O'Sullivan L, Murphy B, McLoughlin P, Duggan P, Lawlor PG, Hughes $\mathrm{H}$, et al. Prebiotics from marine macroalgae for human and animal health applications. Mar Drugs. 2010;8 (7):2038-64.

11. Sims JJ, Donnell MS, Leary JV, Lacy GH. Antimicrobial agents from marine algae. Antimicrob Agents Chemother. 1975;7 (3):320-1.

12. Ganesan P, Kumar CS, Bhaskar N. Antioxidant properties of methanol extract and its solvent fractions obtained from selected Indian red seaweeds. Bioresour Technol. 2008;99 (8):2717-23.

13. Gonzalez del Val A, Platas G, Basilio A, Cabello A, Gorrochategui J, Suay I, et al. Screening of antimicrobial activities in red, green and brown macroalgae from Gran Canaria (Canary Islands, Spain). Int Microbiol. 2001;4 (1):35-40.

14. Blois MS. Antioxidant Determinations by the Use of a Stable Free Radical. Nature. 1958;181 (4617):1199-200.

15. Tachakittirungrod S, Okonogi S, Chowwanapoonpohn S. Study on antioxidant activity of certain plants in Thailand: Mechanism of antioxidant action of guava leaf extract. Food Chem. 2007;103 (2):381-8.

16. Singleton VL, Orthofer R, Lamuela-Raventos RM. [14] Analysis of total phenols and other oxidation substrates and antioxidants by means of folin-ciocalteu reagent. In: Lester P, editor. Methods Enzymol:Academic Press; 1999. p. 152-78.

17. Tortora GJ, Funke BR, Case CL. Microbiology: An Introduction, including Microbiology Place (TM) Website, Student Tutorial CDROM, and Bacteria ID CD-ROM (7th Edition). edition. Benjamin Cummings Publishing SF, USA, editor. ; 2001.

18. Molyneux $P$. The use of the stable free radical diphenylpicrylhydrazyl (DPPH) for estimating antioxidant activity. Songklanakarin J Sci Technol. 2004;26 (2):211-9. 
19. Cowan MM. Plant products as antimicrobial agents. Clin Microbiol Rev. 1999;12 (4):564.

20. Kapasakalidis PG, Rastall RA, Gordon MH. Extraction of polyphenols from processed black currant (Ribes nigrum L. ) residues. J Agric Food Chem. 2006;54 (11):4016-21.
21. Chung KT, Wong TY, Wei CI, Huang YW, Lin Y. Tannins and human health: a review. Crit Rev Food Sci Nutr. 1998;38 (6):421-64.

22. Siddhanta A, Mody K, Ramavat B, Chauhan V, Garg H, Goel A, et al. Bioactivity of marine organisms: Part VIII-Screening of some marine flora of western coast of India. Indian J ExP Biol.1997;35 (6):638. 